\title{
Cooperation of hydrologists from the Danube River Basin
}

\author{
Stevan Prohaska. ${ }^{1}$, Mitja Brilly ${ }^{2}$, Andrej Kryžanovski ${ }^{2}$ \\ ${ }^{1}$ Jaroslav Černi Institute for the Development of Water Resources, Belgrade, 1000, Serbia \\ $5 \quad{ }^{2}$ University of Ljubljana, Ljubljana, 1000, Slovenia
}

Correspondence to: Mitja Brilly (mbrilly@fgg,uni-lj.si)

\begin{abstract}
The development of the hydrology of The Danube River Basin has a long tradition from nineteen century and beyond. Cooperation in hydrology science started 1961 and up to day, 28 conferences have been performed. Since 1975, cooperation between hydrologists of the Danube River Basin has been conducted within the framework of the International

10 Hydrological Programme (IHP) of UNESCO and IHP National Committees established common Cooperation of the Danube River Countries. In addition, Cooperation produce several reports and two books. Cooperation IHP Danube propose common statements for further research and appeal for development water station network necessary for measurement of anthropogenic and climate change impacts
\end{abstract}

\section{Introduction}

15 The development of the hydrology of The Danube River Basin has a long tradition. Data on water levels in catastrophic floods have remained recorded at individual structures since medieval times (Pekarova et al., 2013). Hydrology began to develop more intensively after the Napoleonic wars in the first half of the 19th century. At that time, Bavaria and Austro-Hungarian countries began extensive hydraulics constructions on the regulation of watercourses. In 1826, the Kingdom of Bavaria erected 56 water meters and began systematic observations of the water level, and later in the second half of the 19th century a Hydrographical Bureaus and a similar service were organized in the Austro-Hungarian Monarchy (Schiller et al., 2010). An extensive network of water stations and precipitation stations operated in middle of nineteen centuries in the Danube River Basin.

The needs for navigation on the main stream required establishment of The International Danube Commission (DC), an international intergovernmental organization established by the Convention regarding the regime of navigation on the Danube signed in Belgrade on 18 August 1948. Scientific Cooperation of the Danube countries in the area of hydrology started in 1961, hosting the first conference on hydrological forecast in Budapest. Scientific meetings continued on a biennial basis up to day.

The United Nations declared the Hydrological Decade (IHD) for the decade 1965-1975. International cooperation has begun on a global scale in the field of hydrology during the Cold War. That 10-year program provided an important stimulus to international collaboration in hydrology. IHD was so successful that The General Conference of UNESCO established the International Hydrological Programme (IHP) in 1975 within UNESCO’s Division of Water Sciences. All member states of the 
https://doi.org/10.5194/hess-2020-66

United Nations have formed their National IHP Committees through which overall cooperation in IHP implementation is achieved. A special International Council for IHP was formed at UNESCO in Paris, along with a Secretariat responsible for global IHP implementation, including monitoring and execution of certain themes and projects under a predefined program of activities.

IHP projects are implemented by National IHP Committees of individual countries, National IHP Committees for several countries in the region or in the international river basin, and international and national science associations. Scientific work develops in last decades on UNESCO Chairs and UNESCO first and second category centres. From the scientific point of view, IHP topics are closely linked to the activities of international non-governmental organizations, such as the International Association for Hydrological Sciences (IAHS), the International Association for Hydraulic Research (IAHR), the International Hydrogeologists Association (IAH), the International Irrigation and Drainage Commission (ICID), International Water Resources Association (IWRA), and others.

The IHP International Council, as well as its Secretariat at UNESCO headquarters, is responsible for the implementation of the IHP on a global scale and for monitoring and coordination of the implementation of particular program topics. Each country contributes to its own development by participating in the implementation of individual projects in the International Program, within limits of its material and personnel capabilities. At the same time, the achievements of each country are available to other UNESCO member countries. This knowledge transfer is one of the essential components of UNESCO programs.

Since 1975, cooperation between hydrologists of the Danube River Basin has been conducted within the framework of the International Hydrological Programme (IHP) of UNESCO and IHP NC established common Cooperation of the Danube River

50 Countries.

Cooperation of experts from the Danube countries develops on two activities:

- Organising regional scientific conferences of the Danube countries on hydrological forecasting, and

- Deriving Regional hydrological scientific monographs and thematic projects related to the Danube River Basin.

\section{The Danube River NC IHP Cooperation}

At the beginning, cooperation was related to discharge forecast, but later on the research extended on hydrological bases of the water management. Cooperation began spontaneously on the basis of the needs of the basin countries, burdened by the political division of Europe during the Cold War. The first meeting was organized by the VITUKI Institute in Budapest in 1961, when 25 scientists attended the meeting and presented seven achievements. At the next meeting in Graz in 1963, 14

60 papers were presented and 25 at the 1965 meeting in Bucharest in 1965 (III Conference, 1965). Cooperation continued under the auspices of the hydrological decade and the Danube Commission.

The first conference of the Danube countries on hydrological forecasting was organized in Budapest in 1961, on the initiative of then distinguished scientists in the Danube region (Dumitrescu, Kaczmarek, Kalinin, Lasyloffy and others). The idea was 
https://doi.org/10.5194/hess-2020-66

to bridge the gap between two blocs - at the time the iron curtain was between Danube countries. These conferences of the

Danube countries have acquired a rich tradition as the main gathering point for exchange of experiences and synthesis of hydrological knowledge in the Danube River Basin. From the beginning, the regional conferences of the Danube countries were held every second year, consecutively in each of the eight Danube countries: Germany, Austria, Czechoslovakia, Hungary, Yugoslavia, Bulgaria, Romania and Soviet Union. The order of the host countries was determined at meetings of experts. On the end of last century number of countries increase due transition. So far 28 conferences have been held. The chronological order of the conferences, presentations, the venues, the number of participants, and participants' gender proportions are shown in Table 1. As the number of the Danube countries grew, this regional forecasting conference changed its name to Conference of the Danubian Countries on Hydrological Forecasting and Hydrological Bases of Water Management.

Successful participation in the presentation of national hydrological research at individual conferences triggered the start of joint research work. In order to improve the utilization efficiency of the Danube's water potential and upgrade flood protection, the Danube countries launched an initiative in 1970 to begin the development of a Hydrological Monograph on the Danube River Basin. This initiative was consistent with one of the main objectives of the International Hydrological Decade of IHD UNESCO (1965-1974), to encourage regional cooperation in the field of hydrology in international river basins. At the initiative of DC, work began on the preparation of the water balance of the Danube river basin. The idea was put forward in

80 1971. The work was then very ambitious, but proceeded very slowly because of the political burden and lack of logistics to support such a project (Domokos, 2010).

The first outcome of the regional cooperation of the Danube countries in this regard was the publication of national monographs: "Hydrological balance of the Danube River" produced applying the same methodology in all eight Danube countries. The coordinators of the entire undertaking were:

85 - Institute VUVH from Bratislava which coordinated the work of a group of experts from Czechoslovakia (CS), Hungary (H), Bulgaria BG) and the Soviet Union (SU), and

- Technical Secretariat (NC for IHP YU) from Belgrade which coordinated the work of a group of experts from Germany (D), Austria (A), Yugoslavia (YU) and Romania (RO).

During that period (from 1971 to 1986), experts from all eight Danube countries met every other year and coordinators each

90 year, and agreed to create a single monograph for the entire Danube River Basin. Following harmonization of data and water balance maps between neighbouring countries, the following publications were issued:

1. "Die Donau und Ihr Einzugsgebiet - Eine hydrologische Monographic" in German (München, 1986), and

2. "Donau i ego basseyn - Gidrologicheskaya Monografiya" in Russian, in Leningrad (RSPS 1989).

3. Representative monograph "Danube: hydrology of the river", printed in four languages (English, Russian, German and

95 French) (Stančik A. and Jovanović, S. et al., 1988).

Cooperative work on the monograph has shown that river basin countries need to be more integrated and organized. Representatives of IHP UNESCO NC decided at the meeting in April 1987 in Budapest to continue their cooperation organized 
under the umbrella of IHP UNESCO and adopted the basic principles of cooperation (Domokos 2008). Among other things, the working languages are German and Russian, at least one expert meeting per year is foreseen and currency coordination is foreseen. The political transition in the 1990s caused an increase in the number of countries in the basin. With the collapse of socialist countries in Eastern Europe, new countries were formed in the Danube River Basin (now 19 in total), which also joined the regional cooperation effort under UNESCO IHP. In 2002, the Coordination of the NC IHP of the UNESCO Danube River Basin States updated the principles of cooperation. In principle, English is intended as the working language. Today, active participants in regional cooperation are National IHP Committees of the following countries:

105 IHP National Committees that have signed the "Principles": Germany (D), Austria (A), Czech Republic (CZ), Slovakia (SK), Hungary (H), Slovenia (SL), Croatia (CR), Serbia (SR), Romania (RO), Bulgaria (BG) and Ukraine (UA).

IHP National Committees which have not signed jet the "Principles": Moldova (MD), Bosnia and Herzegovina (BiH) and Montenegro (MN).

The work of experts from the Danube countries is carried out at regular working meetings (once a year in certain countries) and extraordinary working meetings (once in two years - during the Conference of the Danube Countries on Hydrological Forecasting). The working meetings are managed by the country/expert coordinator selected at two-to-three year intervals, each time from another Danube country.

\section{Achievements of cooperation NC IHP UNESCO of Danube River Basin}

115 The monography "Hydrology of the River Danube" is until now the major integrated approach on water regime of the Danube River and its tributaries. Inside the IHP UNESCO Committees cooperation, several common projects are going on supported by modest national sources.

In the period from 1993 to 2017, the above-mentioned Danube countries participated in the implementation of eleven thematic projects. So far, the following projects or subprojects have been completed and published as additional chapters of

120 Monography, while some of the projects are in the process of implementation:

1. Project No 1: Sediment regime of the Danube and its tributaries (Budapest, 1993 - Head Dr. Rakoci, Hungary) - in Russian and German.

2. Project No 2: Thermal and ice conditions of the Danube and its major tributaries (Bratislava, 1993 - Head Dr. Stančikova, Slovakia) - in Russian and German.

125 3. Project No 3: Long-term fluctuations of precipitation in the Danube basin (NK-IHP Austria) - unfinished project.

4. Project No 4: Coincidence of flood flow of the Danube River and its tributaries (Bratislava, 1999 - Head Dr. Prohaska, Yugoslavia) - in English.

5. Project No 5: Reambulation of the Hydrological Monograph of the Danube River Basin 
https://doi.org/10.5194/hess-2020-66

a.

Subproject No 5.1: Inventory of the main hydraulic structures in the Danube Basin (Bucharest, 2004 - Head Dr. Pasoi,

130 Romania) - in English.

b. Subproject No 5.2: Flow regime of the River Danube and its Catchment (Koblenz, 2004 - Head Dr. Belz, Germany)

- in Russian, English and German.

c. Subproject No 5.3: Basin-wide water balance in the Danube River Basin (Bratislava, 2006 - Head Dr. Petrovič, Slovakia) - in English.

135 d. Subproject No 5.4: Characterization of the runoff regime and its stability in the Danube Catchment (Budapest 2006

- Head Dr. Kovacs, Hungary) - in English.

6. Project No 6: The condition of the Danube riverbed

a. Subproject No 6.1: Palaeogeography of the Danube and its Catchment (Budapest, 1999 - Head Dr. Nepel et al.,

140 Hungary) - in English.

b. Subproject No 6.2: The Danube River channel training (Bratislava, 1999 - Head Dr. Stančikova, Slovakia) - in Russian and German.

c. $\quad$ Subproject No 6.3: The fords of the Danube (Budapest, 1993 - Head Dr. Goda, Hungary) - in Russian and German.

d. Subproject No 6.4: Meanders and falls on the Danube River and geomorphological parameters in the riverbed

145 (Analysis of geomorphological processes) - unfinished subproject.

7. Project No 7: Regional analysis of annual peak discharges in the Danube Catchment (Bucharest, 2004 - Head Dr. Stanescu, Romania) - in English.

8. Project No 8: Hydrological bibliography referring to the Danube Basin

150 a. Subproject No 8.1: Hydrological bibliography referring to the Danube River Basin (Koblenz, - Head Dr. Schreoder, Germany) - unfinished subproject

b. $\quad$ Subproject No 8.2: Danube River Basin coding (Ljubljana, 2000 - Head Dr. Brilly, Slovenia) - in English, Russian and German.

155 9. Project No 9: Flood regime of rivers in the Danube Basin (Bratislava, 2019 - Head Dr. Pekarova, Slovakia).

10. Project No 10: Sediment balance in the Danube Basin (Vienna, ??? - Head Dr. Nachtnebei, Austria) - unfinished project. 11. Project No 11: Low flow and hydrological drought in the Danube Basin (Sofia, ??? - Head Dr. Dakova, Bulgaria) unfinished project.

Experts from the Danube countries provide data from their territory for the development of thematic projects, participate in

160 the assessment of results, and approve publication. As a crown to the successful cooperation of the Danube countries, the book "Hydrological Processes of the Danube River Basin - Perspectives from the Danubian Countries" was published by Springer in 2010. It was edited by Mitja Brilly (SLO). 


\section{Further development}

165 The lack of funding in the implementation of projects limits further development in the implementation of research. There are also problems in the status of individual countries regarding EU accession and participation in the part of the Co-operation namely, Bosnia and Herzegovina and Montenegro do not have a designated UNESCO NC IHP. Bosnia and Herzegovina, Montenegro and Serbia are in the process of negotiations for EU accession, and Ukraine and Moldova are just preparing for accession.

170 Water is becoming an increasingly important subject of international cooperation that cannot be properly managed without the necessary knowledge of the water regime and the impact of climate change. The monograph published in 1986 was produced on the basis of data until 1970. The monograph and many research reports need to be updated. That is why at the 17 th meeting in the Golden Sands of 2017 we adopted a resolution on

»Common statement from the participants of the XXVII Danubian Conference on hydrological forecasting and hydrological

175 base of water management:

The scientists participating at the recent XXVII conference have agreed to adopt a common statement with respect to the urgent needs for further systematic and broadly integrated research in the Danube River Basin with the aim of comprehensive further water management research including climate change and anthropogenic impacts that have been emerging for the last centuries. The common statement will be presented to relevant national and international governmental and public bodies responsible

180 for water policy in the Danube River Basin.

The following topics should be analysed and evaluated:

1. Update of the Danube River Basin water balance. Understanding the water balance is essential for protecting the Danube River Basin environment and for water management at large. Without knowledge of the water balance is it not possible to analyse climate change impacts or the transboundary impacts and anthropogenic activities.

$1852 . \quad$ Improving water monitoring. Numerous water gauging stations have been abandoned due to budgetary cuts in some countries, so there is less information available on the water regime than years or even decades before. Numerous new techniques were developed in the recent years and should be implemented. Evaluation of the impacts of climate change and anthropogenic changes cannot neither be justified nor confirmed or properly evaluated without comprehensive and reliable measurements.

190 3. Water management in the Danube River Basin for extreme conditions. We do not know enough about extreme floods and droughts, especially with respect to probable maximum events, of precipitation, floods and droughts. Without data, information and knowledge the magnitudes and implications of such extreme conditions are not known.

4. Snow hydrology is quite well developed in some countries but not over the entire Danube River Basin. Without thorough monitoring and analysis of snow processes, estimates of the water balance and extremes are unreliable. 
https://doi.org/10.5194/hess-2020-66

$1955 . \quad$ Creating an inventory of the major water users (population, industry, agriculture, hydropower, navigation) and their water needs.

6. Testing and implementing improved methods and procedures for analysing of long duration floods and severe droughts, and designing structures and systems aiming at resilient and sustainable human settlements, infrastructure systems and industry complexes.

2007. An updated and refined study should test and extend the results published in the monography »Hydrology of the River Danube« published more than 30 years ago.

8. Hydrological understanding should be furthered in collaboration with other disciplines addressing demographic changes and climate change impacts, such as environmental, management forestry, navigation, development and housing, tourism and other sectors.

$2059 . \quad$ Developing a roadmap for the goals of Water Security and other UN Goals for the coming decades, as given within the IHP UNESCO VIII Phases Programme.

10. Developing of common hydrological and hydraulics regional models for the entire Danube River Basin that are continuously updated as more information becomes available.

11. Monitoring dams and dykes failure consequences related to critical infrastructures on the Danube River and its 210 tributaries.

12. Evaluation and assessment of historical floods in the past, aiming at critical analysis of the methods and procedures for modelling and design projects in multidimensional space, especially at river confluences, using the Balkan floods in the spring of 2014.

13. Historical hydrological information is no less important than the current instrumental information. More efforts

215 should therefore be invested in rescuing and digitizing such information (flood marks, archived data, and various other proxy data) throughout the entire Danube River Basin.

14. Establishing the concept of non-stationarity in the distribution of extreme hydrological and meteorological events as a basis for the definition of calculating hydrographs for the dimensioning of hydro technical facilities that would incorporate anthropogenic influences and the influences of climate change.

220 At the XXVIII meeting in Kyiv, we adopted an appeal to increase terrestrial measurements: »We gained insight into the hydrological circle owing to terrestrial measurements of the individual components of water cycling: precipitation, surface water level and discharge, velocity, air and water temperature, groundwater table, stream flow, evapotranspiration, transpiration, soil moisture, etc. Remote sensing gave new impetus overall and provided the assessment of spatial distribution of the various phenomena. State-of-the-art technology provided measuring probes equipped with computer memory and 225 wireless connection. This development has allowed us to carry out complex hydrological measurements and observations with much smaller resources than in the past. Environmental protection and the expected climate change pose new challenges and require additional, more detailed measurements. Unfortunately, in the Danube River Basin we have witnessed a reduction in the measuring sites for hydrological and meteorological measurements. During the economic crisis that began over a decade 
ago, there were reductions in financial resources in the national services in charge of the measurements mentioned. Many measuring points were abandoned and never restored. The requirements to monitor the various anthropological impacts, environmental protection, and climate change require an increase in the number of measuring points and the introduction of new measuring technologies into practice.

Therefore, the participants of IHP UNESCO's 28th Conference of the Danube Countries appeal to the governments from the Danube River Basin to stop the process of reducing measuring points but, on the contrary, to increase their number. In fact, without additional water stations, realization and our projections of climate change and anthropogenic impact will have higher uncertainty.

A XXIX conference in the Czech Republic is scheduled for 2021. Further research is also envisaged regarding the river temperature regime, low flow rates, etc. Research reports and conferences are digitized and available on the co-operation website.

\section{References}

Brilly M., ed., Hydrological Processes of the Danube River Basin: Perspectives from the Danubian Countries, Springer, doi: 10.1007/978-90-481-3423-6, 2010.

Domokos, M., 2010, History and Results of the Hydrological Co-operation of the Countries Sharing the Danube Catchment (1971-2008), published in Brilly M., ed. Hydrological Processes of the Danube River Basin: Perspectives from the Danubian

Countries, Springer, 1-24, doi: 10.1007/978-90-481-3423-6, 2010.

IHP Danube, Die Donau und Ihr Einzugsgebiet - Eine hydrologische Monographic", Germany, München, 1986.

IHP Danube, Donau i ego basseyn - Gidrologicheskaya Monografiya, Russia, Leningrad, 1989.

Schiller, H., Domokos, M., Sass, J., The Danube River and Its Basin, Brilly M., ed. Hydrological Processes of the Danube River Basin: Perspectives from the Danubian Countries, Springer, 25-78, doi: 10.1007/978-90-481-3423-6, 2010.

III Conference, A III-a CONFERINTA INTERNATIONALA DE PROGNOZE HIDROLOGICE A TARILOR DUNARENE, Bucuresti, Romania, 1965.

Pekárová, P., Halmová, D., Bačová Mitková, V., Miklánek, P., Pekár, J., Škoda, Š, Historic flood marks and flood frequency analysis of the Danube River at Bratislava, Slovakia, J. Hydrol. Hydromech., 61, 4, 326-333, doi: 10.2478/johh-2013-0041, 2013,

255 Stančik A. and Jovanović, S. et al., Danube: hydrology of the river, Priroda, Bratislava, 1988.

Table 1 Conferences of the Danubian Countries on Hydrological Forecasting and Hydrological Bases of Water Management

\begin{tabular}{|c|c|c|c|c|}
\hline Conference & Year & Country & Venue & $\begin{array}{c}\text { Number of } \\
\text { participants }\end{array}$ \\
\hline I & 1961 & Hungary & Budapest & 25 \\
\hline II & 1963 & Austria & Graz & 16 \\
\hline
\end{tabular}




\begin{tabular}{|c|c|c|c|c|}
\hline III & 1965 & Romania & Bucharest & 25 \\
\hline IV & 1967 & Czechoslovakia & Bratislava & 16 \\
\hline V & 1969 & Yugoslavia & Belgrade & 51 \\
\hline VI & 1971 & SU & Kiev & 52 \\
\hline VII & 1973 & Bulgaria & Varna & 42 \\
\hline VIII & 1975 & Germany & Regensburg & 65 \\
\hline IX & 1977 & Hungary & Budapest & 51 \\
\hline X & 1979 & Austria & Vienna & 44 \\
\hline XI & 1982 & Romania & Bucharest & 58 \\
\hline XII & 1984 & Czechoslovakia & Bratislava & 74 \\
\hline XIII & 1986 & Yugoslavia & Belgrade & 49 \\
\hline XIV & 1988 & SU & Kiev & 45 \\
\hline XV & 1990 & Bulgaria & Sofia & 48 \\
\hline XVI & 1992 & Germany & Kelheim & 91 \\
\hline XVII & 1994 & Hungary & Budapest & 127 \\
\hline XVIII & 1996 & Austria & Graz & 138 \\
\hline XIX & 1998 & Croatia & Osijek & 137 \\
\hline XX & 2000 & Slovakia & Bratislava & 252 \\
\hline XXI & 2002 & Romania & Bucharest & \\
\hline XXII & 2004 & Czechia & Brno & \\
\hline XXIII & 2006 & Serbija & Belgrade & 309 \\
\hline XIV & 2008 & Slovenia & Bled & 272 \\
\hline XXV & 2011 & Hungary & Budapest & \\
\hline XXVI & 2014 & Germany & Deggendorf & \\
\hline XXVII & \multirow{2}{*}{2017} & Bulgaria & Golden & \\
\hline XXVIII & 2019 & Ucraine & Kyiv & 74 \\
\hline & \multicolumn{5}{|}{} \\
\hline
\end{tabular}

Table 2: Coordination of the IHP UNESCO NC Cooperation

\begin{tabular}{|c|c|c|c|}
\hline \multirow{2}{*}{$\begin{array}{c}\text { Phase of } \\
\text { cooperation }\end{array}$} & \multirow{2}{*}{ Period } & \multicolumn{2}{|c|}{ Head of coordination } \\
\hline & & Institution(s) & Expert(s) \\
\hline $\mathrm{I}$ & 1971-1986 & $\begin{array}{c}\text { (a) Water resources Institute VUVH, } \\
\text { Bratislava (CS) } \\
\text { (b) Technical Secretariat, Beograd } \\
\text { (YU) }\end{array}$ & $\begin{array}{l}\text { (a) A. Sikora (CS), A. } \\
\text { Stančik (CS) } \\
\\
\text { (b) S. Jovanović (YU) } \\
\text { M. Andjelić (YU) } \\
\text { S. Prohaska (YU } \\
\text { M. Miloradov (YU) }\end{array}$ \\
\hline II & $1987-1992$ & German IHP/OHP National Commitee & K. Hofius (D) \\
\hline III & 1993-1996 & Austrian IHP National Commitee & $\begin{array}{l}\text { O. Behr (A), } \\
\text { D. Gutknecht (A), } \\
\text { F. Nobilis (A) }\end{array}$ \\
\hline IV & 1999-2002 & Slovak IHP National Commitee & P. Miklanek (SK), \\
\hline
\end{tabular}


https://doi.org/10.5194/hess-2020-66

Hydrology and

Preprint. Discussion started: 9 March 2020

(C) Author(s) 2020. CC BY 4.0 License.

Sciences

(c) (1)

Discussions

\begin{tabular}{|c|c|c|c|}
\hline & & & P. Petrovič (SK) \\
\hline V & $2003-2005$ & $\begin{array}{c}\text { Hungarian IHP/OHP National } \\
\text { Committee }\end{array}$ & M. Domokos (H) \\
\hline VI & $2006-2008$ & IHP National Commitee of Serbia & M. Miloradov (SR) \\
\hline VII & $2009-2011$ & IHP National Commitee of Croatia & D. Biondić (CR) \\
\hline VIII & $2012-2017$ & IHP National Commitee of Romania & D. Radulescu (RO) \\
\hline IX & $2017-2020$ & IHP National Commitee of Slovenia & M. Brilly (SI) \\
\hline
\end{tabular}

